
\title{
Besearch S Surare \\ Oil Price Shock and Regime Switching Behaviour of Exchange Rate in Nigeria
}

Taofeek Olusola AYINDE ( $\square$ olusolaat@gmail.com )

Fountain University College of Management Science https://orcid.org/0000-0002-2877-5129

Farouq A. ADEYEMI

PricewaterhouseCoopers

Research

Keywords: Oil Price, Economic Shock, Currency Appreciation, Regime Changes, Trade Balance, H27, E31, F31, C32, F12

Posted Date: September 8th, 2020

DOl: https://doi.org/10.21203/rs.3.rs-68486/v1

License: (1) This work is licensed under a Creative Commons Attribution 4.0 International License. Read Full License 


\title{
OIL PRICE SHOCK AND REGIME SWITCHING BEHAVIOUR OF EXCHANGE RATE IN NIGERIA
}

\author{
Taofeek Olusola, AYINDE (Ph.D. $)^{1}$ and Farouq A. ADEYEMI ${ }^{2}$
}

\begin{abstract}
This study examines the relationship between oil prices and exchange rate in Nigeria by viewing this relationship in another dimension which is the ability of exchange rate to move from one regime to the other. The period of investigation spanned the period $1980-2017$. The regime switching characteristics of exchange rate were examined with the Markov Switching Model technique. The regime switching test suggests that there are two exchange rate regimes of managed float and fixed regimes. It was found that the probability of exchange rate to move from a managed float regime to a fixed regime was very low as compared to switching from fixed to managed float regimes. In fact, the expected duration of transitions is about 4 years for managed float but 9 years for fixed exchange rate regime. Both oil price and exchange rate move in opposite direction; despite the regime changes.
\end{abstract}

\section{Keywords: Oil Price, Economic Shock, Currency Appreciation, Regime Changes, Trade Balance.}

Key Words: H27, E31, F31, C32, F12

\subsection{Introduction}

Krugman (1983) trade balance model focuses on the relationship that exist between crude oil prices and exchange rate changes. In a world constituted of the Organisation for Petroleum Exporting Countries (OPEC), America, and Germany, the trade balance model presupposes that exchange rate need not change as a result of increase in the price of oil. The reason adduced is that the revenue generated from the increase in the price of oil will be used by OPEC to import goods from America and Germany. The prediction of Krugman (1983) serves as the proposition of this study to check whether in Nigeria, the same stance holds. Specifically, oil price increased from \$57 in 2007 first quarter to $\$ 118$ in 2008 third quarter. During the same period, the Naira-Dollar exchange rate also appreciated from 128 Naira per dollar to 118 Naira per dollar. Consequently, oil price

\footnotetext{
${ }^{1}$ Lecturer and Researcher, Department of Economics, Fountain University, P.M.B. 4491, Oke-Osun, Osogbo, Osun State. Correspondences: olusolaat@ gmail.com; ayinde.taofeek@ fuo.edu.ng. Mobile: +234(0)7063357968.

${ }^{2}$ Research Assistant, Fountain University, P.M.B. 4491, Oke-Osun, Osogbo, Osun State.
} 
dropped to $\$ 44$ in 2009 first quarter. During this period, the Naira-Dollar exchange rate exchange rate got depreciated to 147 Naira per dollar. However, exchange rate instability has been very alarming over the years, which has in turn affected the economy in one way or the other. This occurred through lack of confidence on the economy by foreign investors which leads to the reduction in inflow of capital, worsening of the country's balance of payment and other mechanism through which exchange rate instability affects the economy.

The overall intuition is that the instability of exchange rate is of a great concern to the economy as it slows down and hampers the development of the economy. While the Central Bank of Nigeria (CBN) has tremendously activated policies to stabilize this instability over time, the results are still not satisfactory. The question that this study seeks to answer is that is there a relationship between changing oil price and exchange rate fluctuations? Hence, this study seeks to look at oil price and exchange rate relationship; especially with a focus on the various exchange rate regimes in the country. While many studies have investigated the oil price - exchange rate nexus for different countries and have provided various justifications for their studies, this study will be the first to employ a theoretical framework which is that of Krugman (1983) that considers oil price and other variables affecting exchange rate. Most of the previous studies have examined solely oil price and exchange rate dynamics without considering other factors affecting exchange rate. This is being captured in the modified model by including other factors affecting exchange rate but not mentioned in Krugman (1983) model as control variables. Also, this study will be the first to view the oil price-exchange rate nexus in terms of regime switching in Nigeria by using the Markov switching model to estimate the relationship. The study also looked at the relationship through the use of high frequency quarterly data. This data frequency will assists in capturing the various regime switching episodes of exchange rate in tandem with changing oil prices in Nigeria. In addition to this introductory section, this study will further be discussed in four other sections. Section 2.0 considers the review of theoretical and empirical literature while section 3.0 provides analytical framework for empirical investigation. Section 4.0 detailed the estimations while section 5.0 captures the conclusion and the recommendations for policy formulations. 


\subsection{Literature Review}

The theoretical relationship between oil price and exchange rate has been well espoused in the literature. The theoretical literature has recorded four (4) major theories. These are the Dutch disease phenomenon, the Hotelling (1931) theory of exhaustible resource, Dornbusch (1976) Overshooting hypothesis and the portfolio-balancing theory of Krugman (1983). The Dutch disease phenomenon was first coined by the Economist magazine in 1977 but later popularised by Corden and Neary (1983). The theory is primarily associated with a natural resource discovery that resulted in a large influx of foreign currency into a country, including foreign direct investment, foreign aid or a substantial increase in natural resource price. The theory predicted that a resource boom affects the rest of the economy through two channels. The first is the resource movement effect and the second is the spending effect. With an increasing return to marginal productivity of labour in the energy sector, wages in this sector increases and further attracts labour from manufacturing and other tradable sectors into the energy sector. The productivity of the other sectors fall due to absence of labour factor. Given that the marginal productivity of labour in the energy sector brings about a boom and more income to the economy, the spending effect emerge through increase importation and domestic absorption for both tradable and non-tradables. The real exchange rate appreciates as the prices and wages of non-tradables increase relative to tradables due to the price internationalization of the tradable goods (Corden and Neary, 1983).

The Hotelling theory is a decision theory of non-renewable energy resource. According to Hotelling (1931), the future value of non-renewable energy has to be compared to its discounted present value before decision as to whether sales should be made today or in the later future could be decided. The theory presumed that the owners of non-renewable resources will only produce a supply of their basic commodity if it can yield more than available financial instruments. The theory posited that the major driving force for sales decision of non-renewable energy resource is profit maximization under a perfect cum efficient market condition. In addition, Dornbusch (1976) introduced a theory of exchange rate overshooting. This theory was later extended by Driskill and McCafferty (1982). Later, Turnovsky and Bhandari (1982) refined the Driskill and McCafferty (1982) extension. The basic theory explains an over-reaction of monetary policy-inducement to exchange rate volatility and that short-term effect of this volatility would exceed its long-term effect. This occurs due to prices and wage stickiness in the short-run and that as time passes, prices 
and wages become 'unsticky' and this dissipate the initial over-reaction for the long-run situation at a new equilibrium position for all markets. The additions made by Driskill and McCafferty (1982) and the refinement done by Turnovsky and Bhandari (1982) were to further interrogate the origin of shock that hits the economy through the exchange rate volatility. The former found that trade balance and relative prices were correlated with the spot and forward exchange rates while the latter concluded that the balance of payment position is a determining factor.

Lastly, the Krugman's (1983) theory of portfolio balancing is a dynamic partial equilibrium model that explains how increase in the international price of oil influences the exchange rate. As a restrictive theory, it assumes three stakeholders of the United States of America, Germany and the Organisation of Petroleum Exporting Countries (OPEC) and it posited that there exists thresholds for appreciation and depreciation of domestic currency consequent upon oil price increases. According to Krugman (1983), there are perfect counteracting effects between oil price increases and importation of goods that leave the domestic currency unaffected in the long-run situation. The increase in oil price leads to appreciation of domestic currency and this increase income. The increase in income leads to increases in consumption and importation increases. The increased importation leads to depreciation of domestic currency that perfectly commensurate the initial appreciation. An extension to the Krugman's (1983) portfolio balancing theory was carried out by Caprio and Clark (1981). The duo modelled the effect of oil price shocks as a wealth transfer between oil-exporting and oil-importing countries. This extension reinforces that exchange rate will only remain same if perfect asset preference holds between the importing and exporting countries. Otherwise, the counteracting effects will not hold.

Empirically, the effect of oil price shock on exchange rate is different in oil exporting and oil importing countries. When oil price increases, the exchange rate of an oil exporting country tends to appreciate as it now gains more inflow of income, while that of an oil importing country tends to depreciate as a result of the increase in its outflow in relation to its inflow. This gives an insight into how the review of empirical literature can be captured. The empirical literature is therefore divided into four categories. The first category capturing studies that have been done in net oil exporting countries, the second category capturing that of net oil importing countries, the third category capturing studies that encompasses both net oil importing and net oil exporting countries, 
while the fourth category hinged on measurement distinctions of the relationship. Prominent among the studies that investigated for net oil exporting countries were those of Adeniyi, Omisakin, Yaqub, and Oyinlola (2012), M and Aimer (2016), Alzyoud, Wang, and Basso (2018), Wu and Yu (2017), Eugene (2016), Ogundipe, Ojeaga, and Ogundipe (2014), Babatunde, (2015), Englama, Duke, Ogunleye, and Isma'il, (2010), Benhabib, Mohammed, and Maliki (2014), Hashimova (2017), Hasanov, Mikayilov, Bulut, Suleymanov, and Aliyev (2017), Fedoseeva (2017), Djebbouri (2018), Osuji, (2015), Muhammad, Suleiman, and Kouhy (2011), Narayan, Narayan, and Prasad (2008), Rickne (2009), Salisu and Mobolaji (2013), among others.

These studies are further classified into studies that reported oil price increase leading to appreciation of the exchange rate and the ones that reported otherwise. The studies of Adeniyi, Omisakin, Yaqub and Oyinlola (2012), Babatunde (2015), Hashimova (2017), Hasanov, Mikayilov, Bulut, Suleymanov, and Aliyev (2017), Narayan, Narayan, and Prasad (2008), and Wu and $\mathrm{Yu}$ (2017) found out that a positive oil shock which implies increase in oil prices leads to the appreciation of the domestic currency. The increase in oil price to depreciate the domestic currency were reported by the studies of M and Aimer (2016), Eugene (2016), Ogundipe, Ojeaga, and Ogundipe (2014), Benhabib, Mohammed, and Maliki (2014), Muhammad, Suleiman, and Kouhy (2011), and that of Salisu and Mobolaji (2013). However, the following studies confirmed oil price shock to affect exchange rate volatility in net oil exporting countries; Englama, Duke, Ogunleye, and Isma'il (2010), Fedoseeva (2017), Djebbouri (2018), Osuji (2015).

Studies that were done for net importing countries are that of Ahmed, Qaiser and Yaseen (2016), Kaushik, Nag and Upadhyaya (2014), Brahmasrene, Huang and Sissoko (2014), Nouira, Amor and Rault (2018), Dogan, Ustaoglu and Demez (2012), Fowowe (2014), Ghosh (2010), Kin and Courage (2014), Ji, Liu and Fan (2018), Lizardo and Mollick (2009), Jiranyakul (2015), Coudert, Mignon and Penot (2005), Dawson and Jennifer (2007), Tiwari, Dar and Bhanja (2013), among others. The studies of Kaushik, Nag, and Upadhyaya (2014), Fowowe (2014), Ghosh (2010), Lizardo and Mollick (2009), Dawson and Jennifer (2007) all confirmed that an increase in oil prices leads to depreciation of the exchange rate. Ahmed, Qaiser and Yaseen (2016) reported that negative shock in oil price and exchange rate have larger effect on their volatilities than positive shocks. Brahmasrene, Huang and Sissoko (2014) view this relationship in another form as it was 
obtained that exchange rate shock has a significant negative impact on crude oil prices while impulse response of exchange rate variable to a crude oil price shock was statistically insignificant. Ji, Liu, and Fan (2018) observed that there is a significant risk spillover from crude oil to the Chinese and US exchange rate markets. Coudert, Mignon and Penot (2005) found that there is a long-term relationship between oil price and the US exchange rate.

Studies that were done for both net oil importing and exporting countries are those of De Truchis and Keddad (2014), Ahmad and Hernandez (2013), Nouira, Amor and Rault (2018), El Abed, Amor and Nouira (2016), Volkov and Yuhnb (2016), Selmia, Bouoiyourb and Ayachic (2012), Ferraro, Rogoff, and Rossi (2015), among others. De Truchis and Keddad (2014) observed that there is a long-run independence for the Canadian and Japanese exchange rates while few evidence of long-run dependence was found for the European and British exchange rates. Nouira, Amor, and Rault (2018) obtained that foreign exchange market and crude oil exhibit asymmetric and nonasymmetric in the MENA region. El Abed, Amor and Nouira (2016) observed that there is no dynamic relationship among oil prices and exchange rate volatility; also in the MENA region. Selmia, Bouoiyourb and Ayachic (2012) obtained that whether for importing or exporting-oil economy, the real price of oil was negatively and significantly related to the variability of real exchange rate, which is remarkable across all estimates and all the effects considered. Ferraro, Rogoff, and Rossi (2015) revealed that oil prices can predict commodity currencies exchange rates in the United States and Canada.

The fourth category suggests that various techniques have been used over the years in measuring the relationship of oil prices and exchange rate volatility, which might be due to some reasons or the other. De Truchis and Keddad (2014) employed Fractional cointegration and copula techniques; Adeniyi, Omisakin, Yaqub and Oyinlola (2012), Ahmed, Qaiser and Yaseen (2016), Abdelkefi and Khoufi, (2016), Kin and Courage (2014), Muhammad, Suleiman and Kouhy (2011), Narayan, Narayan and Prasad (2008), Aloui, Aissa and Nguyen (2013), among others employed the GARCH, EGARCH, and other extension of the ARCH type techniques due to the finding of ARCH-type effect. Salisu and Mobolaji (2013) utilized the VAR-GARCH model to capture the probable interactions in the conditional returns, volatility and correlations between oil price and exchange rate is underscored by its simplicity in dealing with cross-market volatility spillover 
effects and statistical complications. El Abed, Amor and Nouira (2016) utilized GJR-GARCH because it extends the standard GARCH model to include asymmetric terms that capture an important phenomenon in the conditional variance of equities: the propensity for the volatility to rise more subsequent to large negative shocks than to large positive shocks known a leverage effect. Ogundipe, Ojeaga and Ogundipe (2014) employed the Johansen maximum likelihood estimation procedure and the vector error correction model (VECM) to investigate the relationship between crude oil prices and exchange rate volatility in Nigeria.; while the former enables to determine cointegration rank of their model, the later helps to ascertain possibility of error correction as the model approaches it long run equilibrium path.

Ahmad and Hernandez (2013) in investigating the long-run relationship and asymmetric adjustment between the real oil prices and the real bilateral exchange rates, employed Threshold autoregressive, TAR, and momentum threshold autoregressive, M-TAR model because most of the countries covered in the study are on de jure floating exchange rate regimes. Benhabib, Mohammed, and Maliki (2014) employed the VAR Model (Vector Autoregressive Model) to investigate the relationship between oil price and the nominal US Dollar/Algerian Dinar exchange rate as a result of the need for structural modeling by treating every endogenous variable in the system as a function of the lagged values of all of the endogenous variables in the system. Nouira, Amor and Rault (2018) employed the Asymmetric non-causality test, generalized impulse response, and non-causality in-variance to inspect the oil price fluctuations and exchange rate dynamics in the Middle East and North Africa (MENA) Region. Asymmetric non-causality test was used because the conventional Granger non-causality test (GC) cannot distinguish between the causal impact of positive and negative shocks. Hasanov, Mikayilov, Bulut, Suleymanov and Aliyev (2017) employed the Autoregressive Distributed Lag Bounds Testing Approach to examine the effect of Oil Price Fluctuations on the Exchange Rate of the National Currency of Azerbaijan. The approach according to them outperforms its counterparts, in the case of small samples among its other advantages, such as: being easy to perform just by using OLS; estimating long-and shortrun coefficients, simultaneously; applicability regardless of regressors being $\mathrm{I}(1)$ and $\mathrm{I}(0)$ or a mixture of them. It is of this that a view of regime switching behavior of exchange rate should be presented to capture the relationship between oil price and exchange rate volatility in a new dimension. 


\subsection{Methodology}

The theoretical framework for this study is the Krugman (1983) model. The model is anchored on a trade balance portfolio model of exchange rate determination. The basic model predicts that for a small economy with capital mobility, changes in oil price yields a counteracting effect on exchange rate movement in country through trade adjustment mechanisms. The domestic currency earlier appreciates on the attendant increase in oil price and later depreciates due to increased imports necessitated by increased income. For an oil-exporting country with an exogenously fixed international price of oil denoted as $P_{0}$, the trade balance model can be specified as;

$O_{B}=P_{0} Q_{0}+\left(X_{A}-M_{B}\right)$

The trade balance of the oil-exporting country is denoted as $O_{B}$; Price of oil is represented by $P_{0}$, while $Q_{0}$ represents the total quantity of oil supplied by OPEC; $X_{A}$ Represents export of other commodities to America and Germany excluding oil; $M_{B}$ Represents import of other commodities from America and Germany excluding oil.

Since OPEC fixes price of oil exogenously, exchange rate will only determine the export and import of other goods given as;

$$
\begin{aligned}
& X_{A}=E_{r} X_{a} \\
& M_{B}=E_{r} M_{b}
\end{aligned}
$$

$X_{a}$ is the total quantities of exported goods, $M_{b}$ is the total quantities of imported goods, and $E_{r}$ represents exchange rate.

$O_{B}=P_{0} Q_{0}+\left(E_{r} X_{a}-E_{r} M_{b}\right)$

$O_{B}=P_{0} Q_{0}+E_{r}\left(X_{a}-M_{b}\right)$

Including capital movement

OPEC will invest in America and Germany

$O_{B}=P_{0} Q_{0}+E_{r}\left(X_{a}-M_{b}\right)-C_{0}$

Where $C_{0}$ represents capital flow to America and Germany

$X_{a}-M_{b}=X^{n}$

Where $X^{n}$ is the net export of other goods excluding oil

$O_{B}=P_{0} Q_{0}+E_{r}\left(X^{n}\right)-C_{0}$ 
A few modifications were done to the basic model in order to reflect the reality of the contemporary global oil market. The restrictive assumption of USA and Germany as the only trading partners is relaxed. The world now consists of all countries of the world such that any variable with respect to America and Germany will now be for the whole world. By definition, the variables in equation (6) are now redefined thus;

$O_{B}$ is the trade balance of Nigeria and the rest of the world; $C_{0}$ now is the net capital flow of Nigeria. Re-specifying equation (8) gives;

$E_{r}\left(X^{n}\right)=O_{B}-P_{0} Q_{0}+C_{0}$

Deflating the whole variables with trade balance, we have the theoretical model for this study as;

$E_{r}=\frac{O_{B}}{X^{n}}-\frac{P_{0} Q_{0}}{X^{n}}+\frac{C_{0}}{X^{n}}$

The empirical model for this study becomes;

$E_{r_{t}}=\propto_{0}+\beta_{1} \frac{O_{B}}{X^{n} t}+\beta_{2} \frac{P_{0} Q_{0}}{X^{n}} t+\beta_{3} \frac{C_{0}}{X^{n}} t+\varepsilon_{t}$

Both interest rate and inflation rate are introduced as control variables in the model

$i$ Represents interest rate, while $R_{d}$ represents inflation rate

$E_{r_{t}}=\propto_{0}+\beta_{1} \frac{O_{B}}{X^{n}}+\beta_{2} \frac{P_{0} Q_{0}}{X^{n}} t+\beta_{3} \frac{C_{0}}{X^{n}}{ }_{t}+\beta_{3} i_{t}+\beta_{4} R_{d t}+\varepsilon_{t}$

The study looks at the relationship between oil prices and exchange rate in Nigeria, and the period of investigation spanned 1980 to 2017. The period is well justified as it captures the periods when several exchange rate stabilization policies were embarked upon in Nigeria. More so, this period witnessed various episodes of large variations in the price of crude oil worldwide. The data were obtained at quarterly frequency from the database of the Central Bank of Nigeria (CBN), National Bureau of Statistics (NBS), and International Financial Statistics (IFS). Before the estimations would be done, series of tests would be conducted. The descriptive statistics of the series of the data included in the model would be obtained. This is done in order to know the statistical properties of the variables. Also, the data stability test would be carried out in order to test for the stationary of the data; this would be done using the Augmented Dickey Fuller (ADF) test. The framework for the test can be specified as;

$\Delta y_{t}=b_{1}+b_{2}+w y_{t-1}+\sum_{i=1}^{t} d_{t} \Delta_{t-1}+v_{t}$ 
$y_{t}$ Describes the first difference of $y_{t}$ and the term $\mathrm{m}$ is the lag length of the augmented terms for $y_{t}$ while $V_{t}$ is the error term. The above equation allows for testing of the variable $y_{t}$ to be a stationary series. The null hypothesis in the ADF test is that $y_{t}$ has a unit root or is non-stationary.

The technique of estimation is the Markov switching model of Hamilton (1989) also known as the regime switching model, is one of the most popular nonlinear time series models in the literature. This model involves multiple structures (equations) that can characterize the time series behaviors in different regimes. By permitting switching between these structures, this model is able to capture more complex dynamic patterns. A novel feature of the Markov switching model is that the switching mechanism is controlled by an unobservable state variable that follows a first-order Markov chain. In particular, the Markovian property regulates that the current value of the state variable depends on its immediate past value. As such, a structure may prevail for a random period of time, and it will be replaced by another structure when a switching takes place (Kuan 2002).

The basic Markov switching model can be presented as;

$y_{t}=\mu_{s_{t}}+\sigma_{s_{t}} \varepsilon_{t}$

where $S_{t}=1,2, \ldots \ldots, k$ denotes the unobserved state indicator which follows an ergodic k-state Markov process and $\varepsilon_{t}$ is a zero-mean random variable which is identically and independently distributed over time. The number of states, $\mathrm{k}$, is assumed to be finite. The methodology has been used in empirical work by Engel and Hamilton (1990). The second Markov switching model allows for state-independent autoregressive dynamics:

$$
y_{t}=\mu_{s_{t}}+\sum_{j=1}^{q} \phi_{j}\left(y_{t-j}-\mu_{s_{t}-j}\right)+\sigma_{s_{t}} \varepsilon_{t}
$$

\subsection{Estimations and Analyses}

\subsection{Descriptive Statistics and Statistical Properties}

The statistical properties of the variables included for the model are presented in Table 2. These include both summary statistics such as mean, standard deviation, and skewness. Also, formal statistics of kurtosis and Jarque-bera tests were conducted. As observed below, TRADE BALANCE has the highest mean value of 2867.489 and NET CAPITAL FLOW has the lowest 
mean of -8087.691, for CPI, EXCHANGE RATE, MPR and OIL PRICE are 54.61327, 80.93471, 12.84046 and 39.32871respectively. Also, TRADE BALANCE has the highest median of 696.2332, then followed by EXCHANGE RATE which is 54.32550, and the rest are; 29.52076, 29.04000, 13.00000, and -430.3368 for CPI, OIL PRICE, MPR and NET CAPITAL FLOW.

Table 1: Statistical Properties of Exchange Rate, Oil Prices, Trade Balance, CPI, Net Capital Flow and MPR

\begin{tabular}{|l|c|c|c|c|c|c|}
\hline & CPI & $\begin{array}{c}\text { Exchange } \\
\text { Rate }\end{array}$ & MPR & $\begin{array}{c}\text { Net capital } \\
\text { flow }\end{array}$ & Oil price & $\begin{array}{c}\text { Trade } \\
\text { balance }\end{array}$ \\
\hline Mean & 54.61 & 80.93 & 12.84 & -8087.69 & 39.33 & 2867.49 \\
\hline Median & 29.521 & 54.33 & 13.00 & -430.34 & 29.04 & 696.23 \\
\hline Maximum & 244.78 & 305.95 & 26.00 & 3470.90 & 120.97 & 44731.20 \\
\hline Minimum & 0.36 & 0.54 & 6.00 & -138755.6 & 0.00 & -19488.70 \\
\hline Standard & 1.21 & 0.81 & 0.48 & -4.37 & 0.99 & 2.61 \\
\hline deviation & 63.57 & 80.56 & 4.11 & 24105.91 & 31.19 & 10408.36 \\
\hline Skewness & 3.49 & 3.12 & 3.62 & 23.29 & 3.04 & 11.66 \\
\hline Kurtosis & & & & & & \\
\hline Jarque- & 38.30 & 16.61 & 8.36 & 3092.71 & 24.91 & 647.13 \\
\hline Pera & 0.00 & 0.00 & 0.02 & 0.00 & 0.00 & 0.00 \\
\hline
\end{tabular}

Source: CBN Statistical Bulletin (2018); World Development Indicators (WDI, 2018).

However, the formal statistics of the kurtosis shows that all the variables are leptokurtic in nature because the values are all greater than 3 . This implies that they are highly peaked with a very high tail. The Jarque Bera is a test for normality of the distribution for the variables. To check whether the error term is normally distributed. In this case, we can see that all the probability value of the variables are lesser than the benchmark of 0.05 which leads to rejecting the null hypothesis that the variables are not normally distributed, implying that the variables are normally distributed. This section starts by looking at the trend analyses of the variables in the model. The price of crude oil at quarterly basis, the official exchange rate also quarterly, and the trend of both of them together. The graphical trend is firstly presented then followed by the tabular trend. The Naira 
maintained from 1980 to 1992 . The Retail Dutch Auction System (RDAS) was reintroduced in July 2002. The policy saw the exchange rate depreciating from N92.7 per dollar in 1999 to N121.0, N129.4, N133.50 and N132.15 per US dollar in 2002, 2003, 2004 and 2005, respectively (Essien, Uyaebo, and Omotosho 2017). The Wholesale Dutch Auction System (WDAS) was introduced on the 20th of February, 2006 to further liberalize the foreign exchange market, reduce the dependence of authorized dealers on $\mathrm{CBN}$ for foreign exchange and achieve convergence in exchange rates. This led to an appreciation of the exchange rate from its level of N132.15/US\$ in 2005 to N128.65/US\$, N125.83/US\$ and N118.57/US\$ in 2006, 2007 and 2008, respectively.

Following the impacts of the global financial crisis on the economy, depreciation pressures mounted on the naira as its exchange rate moved to N148.91/US\$, N150.30/US\$ and N153.90/US\$ in 2009, 2010 and 2011, respectively. These led to the reintroduction of IFEM in November 2013 while the CBN continued to intervene in the market (Essien, Uyaebo, and Omotosho 2017). The Naira depreciated greatly against the US dollar as a result of scraping of the currency peg by the Central Bank of Nigeria which had kept the rate at an artificial value of 198 NGN per USD for over a year which led to the currency losing over $40 \%$ of its value against the USD and fell to 282 NGN per USD. The Naira further depreciated to 285 NGN PER USD as a result of the CBN intervention in the foreign exchange market few weeks after the devaluation. On July 28 , the currency fell to a record of 322 NGN per USD, which marked a 14.2\% depreciation over the same day in June and a $61.8 \%$ depreciation in annual terms.

In 1990, an oil price spike occurred as a result of Iraqi invasion of Kuwait which led to the reduction in the supply of oil in the world thereby leading to the increase in the price of oil. As the US led coalition experienced military success against Iraqi forces, concerns about long term supply shortages eased and prices began to fall. In July 2008, oil price peaked at $\$ 147.30$ as a result of some factors which are; tension in the Middle East, soaring demand from China, the falling value of the US dollar, and reports showing decline in petroleum reserves, worries over peak oil, and financial speculation. But the price fell to $\$ 32$ in December as a result of the global recession which had reduced demand of oil thereby leading to the price of oil. As a result of OPEC cutting its supply in order to stabilize the oil price in the international oil market, oil prices stabilized by August 2009 and generally remained in a broad trading range between $\$ 70$ and $\$ 120$ through 
November 2014. Oil price dropped in 2015 below $\$ 40$ which is as a result of the strong US dollar and the unwillingness of OPEC to stabilize the oil markets. Some part of it intended to reduce its production, but the leaders mainly Saudi Arabia, UAE, and other Gulf allies refused to cut their production. However, Iraq was the only country that not only maintained its supply, but actually increased it. This resulted in an oversupply of oil, which in turn placed downward pressure on crude oil prices for the long term. Also US saw this as an opportunity and increased its production which further led to the decline in crude oil prices.

The trend in Figure 1 is very instructive about the behavior of exchange rate in Nigeria. Exchange rate was relatively stable up to the year 1988. There was a relative leap in exchange rate since the fourth quarter of 1988 but the increase in the domestic rate of naira to the international referenced currency of dollar increased further till the fourth quarter of the year 1998. A sharper increase was noticed since 1999up to the year 2008 and further increased to N150 to US\$1. Between 2015 and second quarter of 2016, it increased further to N196 to US\$1. By the third quarter of 2016 till the fourth quarter of 2017, it has increased to above N300; precisely N306.50 to US\$1 (see Figure 1). Some important macroeconomic fundamentals and dynamics responsible for this exchange rate behavior are the Structural Adjustment Programme (SAP) of 1986, the democratic dispensation that began in 1999 and the economic crises of 2016. The fact that Nigeria is a small open economy, the global economic recession between the period 2007 and 2009 also impacted on the behavior of exchange rate in the country. 


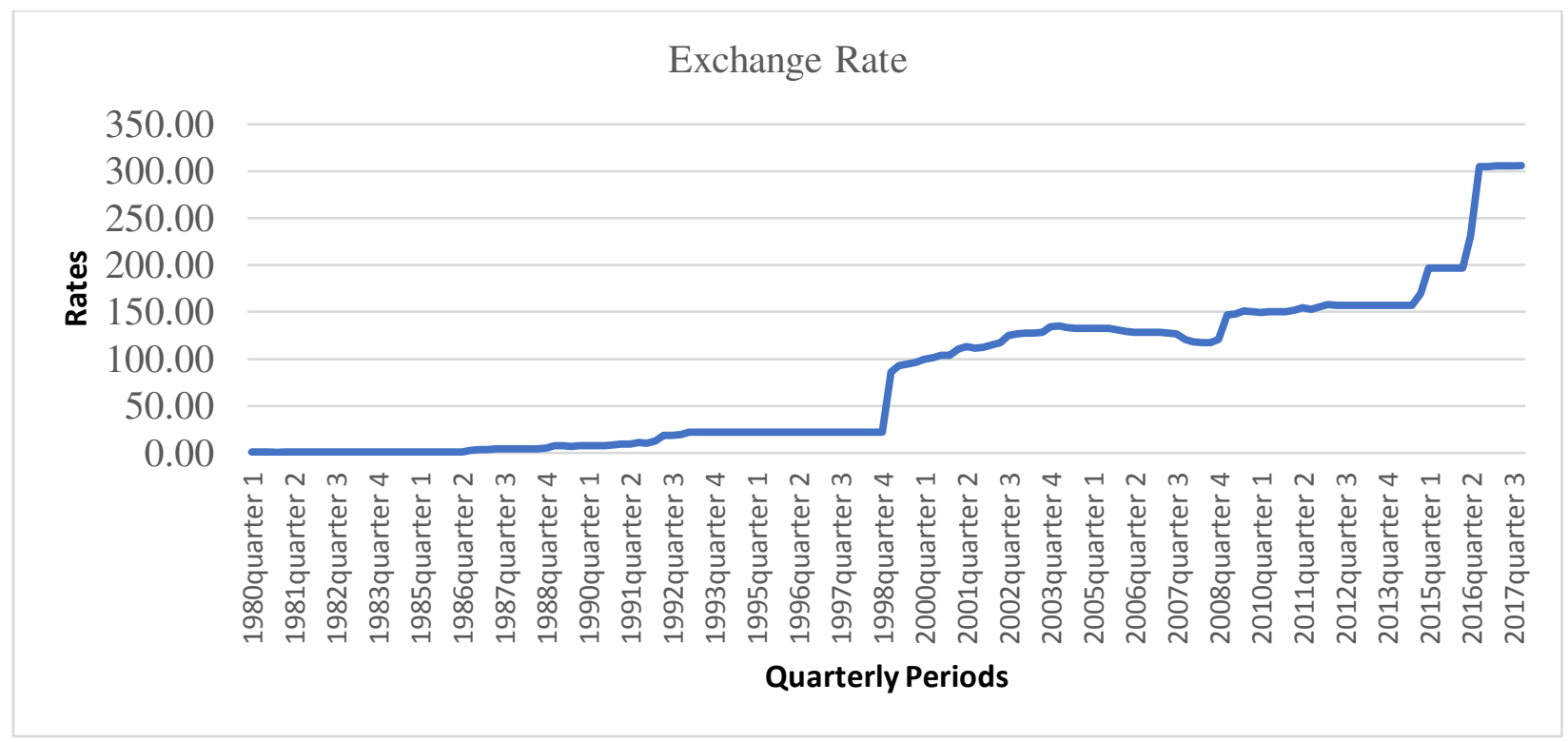

Figure 1: Exchange Rate (US\$:N1) Movement in Nigeria Source: CBN Statistical Bulletin (2018); World Development Indicators (WDI, 2018).

Also, Nigeria, as a member of the Organisation of Petroleum Exporting Countries (OPEC), is expected to be subjected to the dictates of the international cartel. With this, the prices to sell and the quantity of oil to be sold are exogenous factors that determine the movement in the price of oil. Nigeria is the fourth largest oil producing countries in the world and oil explorations account for the major source of foreign reserve. As a result, the position of the balance of payment account will reflect on the exchange rate dynamics of the Nigerian economy. As depicted in Figure 2, oil prices are strongly volatile throughout the period under consideration. There are strong spikes that coincide with important historical occurrences such as the $2007-2009$ global economic crises, the 2016 oil shock. These two occurrences culminated in exchange rate depreciation in the country. 


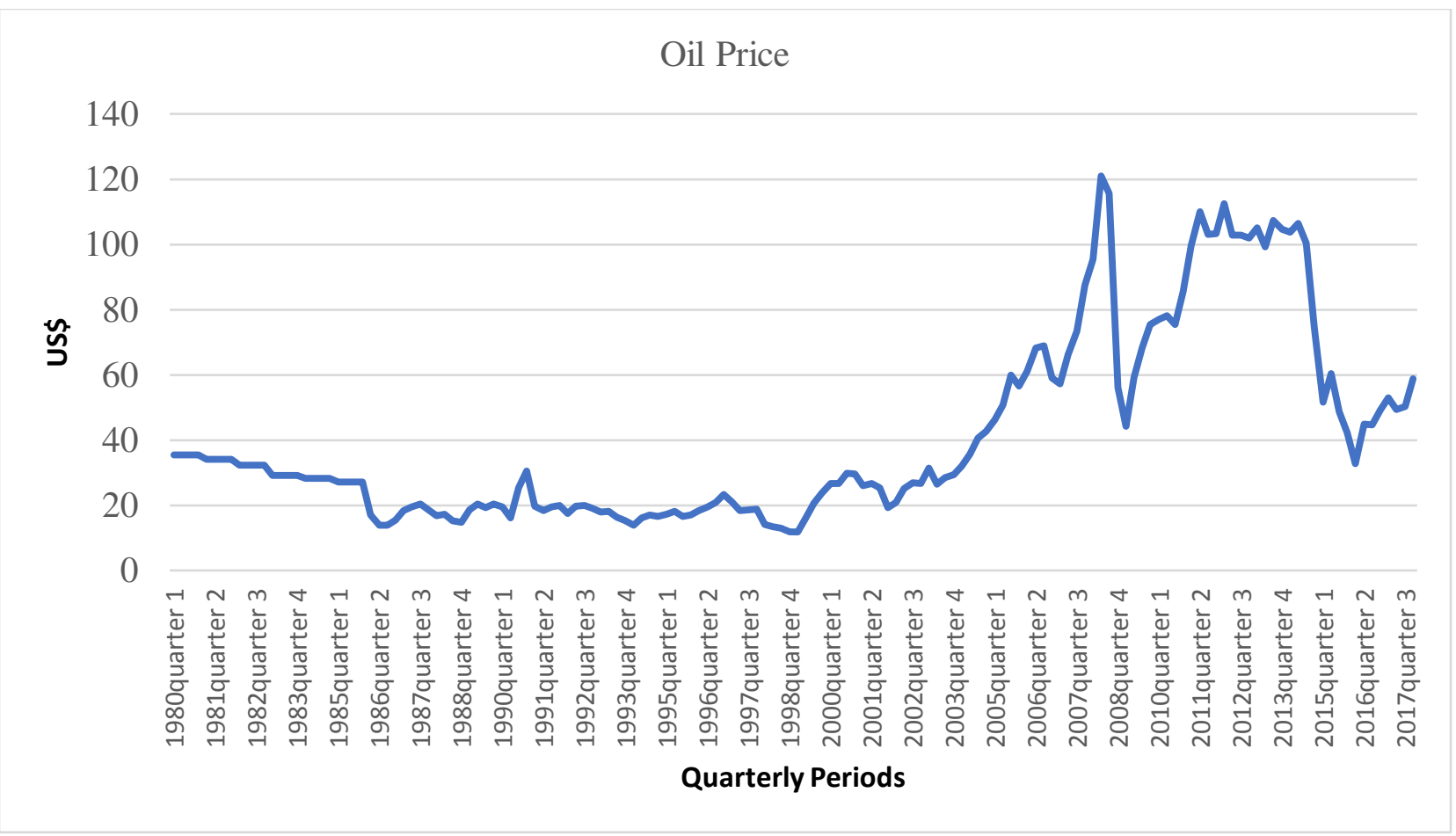

Figure 2: International Oil Price

Source: CBN Statistical Bulletin (2018); World Development Indicators (WDI, 2018).

The trend in Figure 3 is very instructive about the relationship between exchange rate behavior and oil price dynamics in Nigeria. Both variables are largely negatively related such that an increase in the international prices of oil indicates a fall in the value of exchange rate of naira to the international reference currency of dollar. This suggests exchange rate appreciation. On the other hand, a fall in the international prices of oil denotes exchange rate depreciation. The implication is that Nigeria, as an oil-dependent economy, has its domestic currency largely susceptible to the prices of oil in the international market (see Figure 3). Between 1980 and 1992, there is a fall in the exchange rate; denoting exchange rate appreciation consequent upon increase in the international price of oil. However, there is exchange rate depreciation due to fall in the international price of oil between quarter 1 of 199 to quarter 1 of 2008. In reverse, exchange rate has continues to depreciate due to occurrences of global economic crises and the crash in the oil market in the year 2016. Hardly has the currency recover from the first shock that the second shock occurred. 


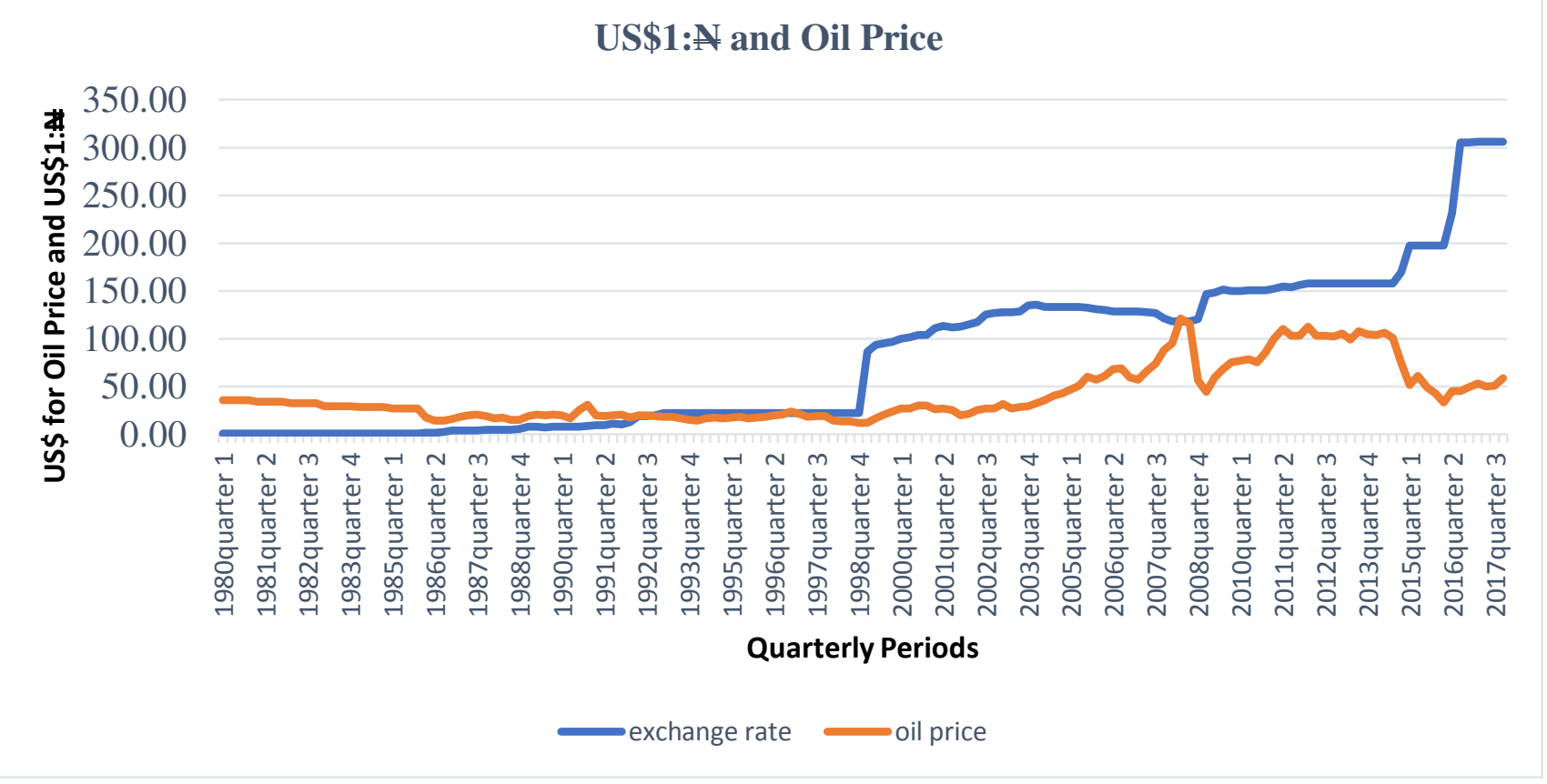

Figure 3: Exchange Rate Movement in Nigeria and International Price of Oil Source: CBN Statistical Bulletin (2018); World Development Indicators (WDI, 2018).

\subsection{Data Stability Condition}

Before the estimation proper, the data stability test is being carried out to check for the stationarity of the data. The test considered in this study is the Augmented Dickey Fuller (ADF) test as shown in table 2. The statistics obtained shows that MPR, NET CAPITAL FLOW, and TRADE BALANCE are of order I(0), which implies that the data are pure and raw and are stationary at level. Log (CPI), EXCHANGE RATE, and OIL PRICE are of order I(1) and this implies that the data are purified, that is not pure and raw which calls for integrating the variables. This implies that the data are stationary at first difference.

Table 2: Augmented Dickey Fuller (ADF) Unit Root Test

\begin{tabular}{|l|c|c|c|c|c|}
\hline & \multicolumn{2}{|c|}{$\mathrm{I}(0)$} & \multicolumn{2}{c|}{$\mathrm{I}(1)$} & $\mathrm{Hi} ; \mathrm{p}<0.05$ \\
\hline Variables & P Value & T statistics & P Value & T statistics & Integration Order \\
\hline Log(CPI $)$ & 0.607 & & & & \\
\hline \\
EXCHANGE
\end{tabular}




\begin{tabular}{|l|c|c|c|c|c|}
\hline $\begin{array}{l}\text { NET } \\
\text { CAPITAL } \\
\text { FLOW }\end{array}$ & 0.119 & $-2.298^{* *}$ & & & \\
\hline & & & & & \\
OIL PRICE & 0.547 & & 0.0000 & $-10.201 *$ & $\mathrm{I}(1)$ \\
\hline $\begin{array}{l}\text { TRADE } \\
\text { BALANCE }\end{array}$ & & & & & \\
\hline
\end{tabular}

Source: CBN Statistical Bulletin (2018); World Development Indicators (WDI, 2018). Note: $(*, * * * *)$ implies that the series is non-unit root at $1 \%, 5 \%$, and $10 \%$ level.

After the data stability test has been carried out, the next thing is to estimate the Markov Switching Model. Theoretically, exchange rate can be into two regime, which are; the floating and the fixed regime. The floating regime can thereby be into two categories, namely; the free float regime and the managed float regime. The fixed regime also known as the pegged exchange rate regime is when transactions about exchange rate takes place at an exchange rate determined by solely by the monetary authority. The exchange rate might be fixed by legislation or intervention in the currency market. The monetary authority might buy or sell currencies according to the needs of the country, or may take policy decisions to appreciate or depreciate the national currency. In most fixed exchange rate regime, the monetary authority holds foreign currency reserves in order to intervene in the foreign exchange market, when demand and supply of foreign exchange are not equal at the fixed rate. The floating regime, also known as the flexible regime is when the exchange rate is left to be determined by the forces of demand and supply. The floating regime can be into the free float and the managed float. The free float regime implies that the market forces of the demand and supply of foreign exchange determines the exchange rate.

The managed float regime also known as the dirty float regime is when the exchange rate is basically determined by the free forces of demand and supply of exchange rate, but the monetary authority intervenes from time to time to control excessive fluctuations in exchange rate. By using the Markov switching model, the type of exchange rate regime can be known through the coefficient. If the coefficient of state is zero, it implies a free floating exchange rate regime. If the coefficient of the state is larger let's say 100 upward, the exchange rate regime can be identified 
as a fixed regime. But if the coefficient is not too large and not zero, but tending towards zero, the exchange rate regime can be identified to be a managed float, let's say like 30 to 0 .

\subsection{Model Estimations and Discussion of findings}

Results obtained show that there are two regimes of exchange rate in Nigeria. The first regime (State 1) has 10.602 coefficients. This implies that the state is a managed float regime while the second regime (State 2) has coefficients of 152.4682; which implies that state 2 is a fixed exchange rate regime. The significance of the two regimes are significant are further reinforces the presence of two regimes of exchange rate in Nigeria.

Table 3: Detecting the Number and Type of States.

\begin{tabular}{|l|l|l|l|l|}
\hline No of States & Coefficients & Std Error & Z statistics & Prob \\
\hline State 1 & 10.60194 & 4.3918 & 2.41 & 0.016 \\
\hline State 2 & 152.4682 & 4.3949 & 34.69 & 0.000 \\
\hline
\end{tabular}

Source: CBN Statistical Bulletin (2018); World Development Indicators (WDI, 2018).

After detecting for the number of states and the types that they are, the next thing is to know the transition probabilities and the intuition behind it. This can be seen as the probability of exchange rate moving from a managed float regime to a fixed float regime, and vice versa. P11 is the probability of exchange rate moving from a managed float regime to a managed float regime. It can be seen that the probability of exchange rate moving from a managed float regime to a manage float regime is $99.34 \%$, which depicts a higher chance of staying in the managed float regime. On the other hand, P12 is the probability of exchange rate moving from a managed float regime to a fixed regime. The probability is $0.66 \%$, which is very low which depicts a very low chance of switching to fixed regime. Also, P21 is the probability of exchange rate moving from a fixed regime to a managed float regime. The probability is $0.67 \%$, which depicts a low chance of exchange rate moving from the fixed regime to the managed float regime. More so, P22 is this probability of exchange rate moving from a fixed regime to a fixed regime. The probability is 99.33\%, which implies that exchange rate has a higher chance of staying in the fixed regime. 
Table 4: Probability of Transition from One State to the Other

\begin{tabular}{|l|c|}
\hline & \\
States & Probability of transmitting from one state to the other \\
\hline P11 & $99.34 \%$ \\
\hline P12 & $0.66 \%$ \\
\hline P21 & $0.67 \%$ \\
\hline P22 & $99.33 \%$ \\
\hline
\end{tabular}

Source: CBN Statistical Bulletin (2018); World Development Indicators (WDI, 2018).

After the number of states which is two, and the types of the states which are the managed float and fixed regime have been identified, the next thing is to know the amount of time exchange rate uses in each of the regime. The total observation of the study is 152 quarters which can be converted into 38 years. The expected duration of exchange rate in each regime will be calculated based on the number of the estimate out of the total observation. Exchange rate is expected to use 152 quarters in the managed float regime. This implies that exchange rate would stay for 38 years in the managed float regime. Exchange rate is expected to use 150 quarters in a fixed regime. This implies that exchange rate would stay for 37 years and a half in the fixed exchange rate regime.

Table 5: Duration of Exchange Rate in the States

\begin{tabular}{|l|c|}
\hline Expected Duration & Estimate \\
\hline Managed Float Regime & 152 \\
\hline Fixed Regime & 150 \\
\hline
\end{tabular}

Source: CBN Statistical Bulletin (2018); World Development Indicators (WDI, 2018).

The above have illustrated the properties of exchange rate in terms of the regime it can be into, the types and nature of the regimes, and duration in each regime. The next thing to do is to incorporate the model as specified earlier in the study. After the estimation, it was found that Oil price has a negative coefficient of -0.2022 which implies that a $1 \%$ increase in oil price leads to a $0.2022 \%$ reduction in exchange rate, and also, we should not forget that a reduction in the exchange rate is an appreciation. Net Capital Flow has a positive relationship with exchange rate. That is, a $1 \%$ increase in Net Capital Flow will lead to a $0.00048 \%$ increase in the exchange rate which 
automatically depicts depreciation in exchange rate. CPI has a positive relationship with exchange rate. That is, a $1 \%$ increase in CPI leads to $0.9023 \%$ increase in exchange rate which depicts depreciation in the exchange rate. Trade balance and the exchange rate exhibits positive relationships. That is, a $100 \%$ increase in trade balance leads to $0.65 \%$ increase in exchange rate which depicts depreciation in the exchange rate. Interest rate and exchange rate exhibits a positive relationship. That is, a $1 \%$ increase in interest rate (MPR) leads to a $2.952 \%$ increase in the exchange rate which depicts depreciation in the exchange rate.

Table 6: The coefficients of the explanatory variables are;

\begin{tabular}{|l|l|l|l|l|l|}
\hline Variables & Oil price & $\begin{array}{l}\text { Net Capital } \\
\text { Flow }\end{array}$ & CPI & $\begin{array}{l}\text { Trade } \\
\text { Balance }\end{array}$ & MPR \\
\hline Coefficients & -0.2022 & 0.00048 & 0.9023 & 0.00065 & 2.952 \\
\hline
\end{tabular}

Source: CBN Statistical Bulletin (2018); World Development Indicators (WDI, 2018).

The transition probabilities of exchange rate were also examined. P11; this is the probability of exchange rate moving from a managed float regime to a managed float regime. It can be seen that the probability of exchange rate moving from a managed float regime to a manage float regime is $93.58 \%$, which depicts a higher chance of staying in the managed float regime. P12 relates to the probability of exchange rate moving from a managed float regime to a fixed regime. The probability is $6.42 \%$, which is very low which depicts a very low chance of switching to fixed regime. $\mathrm{P} 21$ is the probability of exchange rate moving from a fixed regime to a managed float regime. The probability is $2.72 \%$, which depicts a low chance of exchange rate moving from the fixed regime to the managed float regime. P22 is the probability of exchange rate moving from a fixed regime to a managed-float regime. The probability is $97.28 \%$, which implies that exchange rate has a higher chance of staying in the fixed regime. 
Table 7: The Transition Probabilities of Exchange Rate

\begin{tabular}{|l|c|}
\hline States & Probability of transmitting from one state to the other \\
\hline P11 & $93.58 \%$ \\
\hline P12 & $6.42 \%$ \\
\hline P21 & $2.72 \%$ \\
\hline P22 & $97.28 \%$ \\
\hline
\end{tabular}

Source: CBN Statistical Bulletin (2018); World Development Indicators (WDI, 2018).

After incorporating the explanatory variables in the model, the duration of exchange rate in each regime is being checked. The number of observation is still 152 quarters which is 38 years. It was obtained that Exchange rate is expected to stay 15.57 quarters in the managed float regime which is 3.9 years Exchange rate is expected to stay 36.76 quarters in the fixed regime which is 9.2 years

Table 8: The Duration of Exchange Rate Incorporating the Explanatory Variables

\begin{tabular}{|l|c|}
\hline Expected Duration & Estimate \\
\hline Managed Float Regime & 15.57 \\
\hline Fixed Regime & 36.76 \\
\hline
\end{tabular}

Source: CBN Statistical Bulletin (2018); World Development Indicators (WDI, 2018).

\subsection{Conclusion and Policy Suggestion}

This study examines the relationship between oil prices and exchange rate by viewing this relationship in another dimension which is the ability of exchange rate to move from one regime to the other. It is of evidence that exchange rate can be into two states or let's say regimes, which are; the state of a managed float regime and a fixed regime. And it was found that the probability of exchange rate to move from a managed float regime to a fixed regime very low, and also the chance of exchange rate moving from a fixed exchange rate regime to a managed float regime is very low. It was also obtained that exchange rate is expected to stay 15.57 quarters in the managed float regime which is 3.9 years, while exchange rate is expected to stay 36.76 quarters in the fixed regime which is 9.2 years. It was also observed that exchange rate and oil price exhibits a negative relationship; that is, they move in opposite directions whereby when oil prices increase, the exchange rate will reduce which implies appreciation of the currency. It was found that a $1 \%$ 
increase in oil price will lead to a $0.20 \%$ appreciation in the Naira Dollar exchange rate. This clearly implies the fact that Nigeria is an oil exporting country, and an increase in oil price will transfer wealth from oil importing countries to exporting countries. By the implication of the results obtained, the following suggestions are recommended for policy direction.

First, the revenue generated from oil should be channeled into creation of necessary and adequate infrastructural facilities in order to encourage small industries in producing locally made goods. By this, the importation of goods will reduce and the trade balance becomes favourable. Secondly, interest rate should be closely monitored by the central bank, in order to command inflow from abroad increasing the net cash inflow into the country. Thirdly, policies should be harnessed together. In Nigeria, there is a problem of new administration coming with new policies which contradicts the policy of the previous administrations. This is because political party tends to show off with their policies, and this neglects the policies of the previous terms. New government should therefore further with the achievement of good policies started by previous administration.

\section{*Availability of data and material}

The data for this study are available on request.

\section{*Competing interests}

It is instructive to note that there is no competing interesting for this study. The two authors with corresponding email addresses provided here are the contributed to the completion of this manuscript.

\section{*Funding}

Not Applicable

\section{*Authors' contributions}

Dr. T.O. Ayinde contributed to the conceptualization of this manuscript and also undertakes the aspect of analyses, concludes and offer policy recommendation. Mr. F. A. Adeyemi did the review of literature and set up the methodological framework. He also collected the required data for empirical investigations. 


\section{*Authors' information (optional)}

Dr. T.O. Ayinde is the Head, Department of Economics, Fountain University, P.M.B. 4491, OkeOsun, Osogbo, Nigeria. He was a scholar of the African Economic Research Consortium (AERC) during his Collaborative Ph.D. Progamme (CPP) at the University of Ibadan, Nigeria. Mr. F.A. Adeyemi had a First Class (Hons) Degree at the Department of Economics, Fountain University, Osogbo. Currently, Mr. F. A. Adeyemi works at the PriceWaterCoopers (PWC) International, one of the Big Five Accounting Professional Bodies in the World.

\section{*Acknowledgements}

These authors acknowledge the efforts of the Research Committee of the College of Management and Social Sciences (COMAS) of Fountain University, Osogbo to have provided the research platform to present this research work and harvest comments to improve the quality of the work. 


\section{REFERENCES}

Abdelkefi, S, Z, and Khoufi, W (2016). To What Extent Crude Oil, International Stock Markets and Exchange Rates Are Interdependent in Emerging and Developed Countries? Research Journal of Finance and Accounting, Vol.7, No.15, pp 96 - 107.

Adıgüzel, U., Bayat, T., Kayhan, S, and Nazlığlu, Ş (2013). Oil prices and exchange rates in Brazil, India and Turkey: time and frequency domain causality analysis. Siyaset, Ekonomi ve Yönetim Araştırmaları Dergisi, 1, pp 49-73.

Adeniyi, O, Omisakin, O, Yaqub, J, and Oyinlola, A. (2012). Oil Price-Exchange Rate Nexus in Nigeria: Further Evidence from an Oil Exporting Economy, International Journal of Humanities and Social Science Vol. 2 No. 8 [Special Issue - April 2012], pp 113 - 121.

Ahmad, A, H, and Hernandez, R, M (2013). Asymmetric adjustment between oil prices and exchange rates: Empirical evidence from major oil producers and consumers, Journal of International Financial Markets, Institutions \& Money, pp 306 - 317.

Ahmed,V, Qaiser, I, and Yaseen, R, M (2016). Nexus between Exchange Rate Volatility and Oil Price Fluctuations: Evidence from Pakistan, Pakistan Journal of Commerce and Social Sciences 2016, Vol. 10 (1), pp 122 - 148.

Akram, Q.F (2004). Oil Prices and Exchange Rates: Norwegian Evidence, Econometrics Journal, Volume 7, pp 476-504.

Aloui, R., Aissa, M.S. B and Nguyen, D. K. 2013. Conditional Dependence Structure between Oil Prices and Exchange Rates: A Copula-GARCH Approach. Journal of International Money and Finance, 32.

Alzyoud, H, Wang, Z, E, and Basso, M, G (2018). Dynamics of Canadian Oil Price and its Impact on Exchange Rate and Stock Market, International Journal of Energy Economics and Policy 8(3), pp $107-114$.

Backus, D.K, and Crucini, M.J (2000). Oil Prices and Terms of Trade, Journal of International Economics 50, pp 185-213.

Babatunde, M.A (2015)."Oil Price Shocks and Exchange Rate in Nigeria", International Journal of Energy Sector Management, Vol. 9, No. 1, pp 1 - 16.

Benhabib, A, Mohammed, S, I, and Maliki, S (2014). The relationship between oil price and the Algerian exchange rate, Topics in Middle E astern and African Economies Vol. 16, No. 1, pp $127-141$.

Bouoiyour J, Selmi, R, Tiwari, A, K, and Shahbaz, M (2015). The Nexus between Oil price and Russia's Real Exchange rate: Better Paths via Unconditional vs Conditional Analysis, Energy Economics (2015), pp $1-48$. 
Brahmasrene, T, Huang, J, and Sissoko, Y (2014). Crude oil prices and exchange rates: Causality, variance decomposition and impulse response, Energy Economics (2014), pp 1 - 27.

Caprio, J, and Clark, P (1981). Oil Price Shocks in a Portfolio Balance Model, Journal of International Economics, 11, pp 589-602.

Corden, W.M, and Neary, J.P (1982). Booming Sector And De-Industrialisation in a Small Open Economy, The Economic Journal, Vol. 92, No. 368, pp 825-848.

Coudert, V, Mignon, V, and Penot, A (2005). Oil Price and the Dollar, Energy Studies Review, DeGroote School of Business, McMaster University, 2008, 15 (2). pp 1-20.

Dawson '06, and Jennifer C. (2007) "The Effect of Oil Prices on Exchange Rates: A Case Study of the Dominican Republic," Undergraduate Economic Review: Vol. 3: Iss. 1, Article 4. pp 1-25.

De Truchis, G.,and Keddad, B (2014). On the risk comovements between the crude oil market and U.S. dollar exchange rates, Econ Model, pp 1-10.

Djebbouri, M (2018). Impact of Oil Price Shocks on Exchange Rate in Algeria, International Journal of Finance and Accounting, Vol. 7 No. 5, 2018, pp. 133-141

Dogan, S, Ustaoglu, M, and Demez, S (2012). Relationship between Real Oil Price and Real Exchange Rate: the case of Turkey, Procedia - Social and Behavioral Sciences 58 (2012), pp $1293-1300$.

Dornbusch. (1976). Expectations and Exchange Rate Dynamics. Journal of Political Economy, Vol. 84 (December 1976), pp 1161-1176.

Driskill, R, and Mccafferty, S (1982). Spot and Forward Rates in a Stochastic Model of Foreign Exchange Market, Journal of International Economics 12, pp 313-331.

El Abed, R, Amor, T, and Nouira, R (2016). Asymmetric effect and dynamic relationships between oil prices shocks and exchange rate volatility: Evidence from some selected MENA countries, Middle East Economic Association, 15th International Conference, pp 1-24.

Engel, C, and Hamilton, J.D (1990). Long Swings in The dollar: Are They in The data And do markets Know It? American Economic Review 89, pp 689-713.

Englama, A, Duke, O.O, Ogunleye, T, S, and Isma'il, F, U (2010). Oil Prices and Exchange Rate Volatility in Nigeria: An Empirical Investigation, Central Bank of Nigeria Economic and Financial Review Volume 48/3, pp $31-48$. 
Essien S.N, Uyaebo S.O.U, and Omotosho B.S (2017). Exchange Rate Misalignment under Different Exchange Rate Regimes in Nigeria, CBN Journal of Applied Statistics Vol. 8 No. 1 (June, 2017) pp 1-21.

Eugene, I (2016). Dynamic Relationship between Crude Oil Price, Exchange Rate and Stock Market Performance in Nigeria, AFRREV, Vol. 10(4), Serial No.43. pp 224-240.

Fedoseeva, S (2017). Under pressure: Dynamic pass-through of oil prices to the RUB/USD exchange rate, International Economics (2017), pp $1-10$.

Ferraro, D, Rogoff, K, Rossi, B (2015). Can Oil Prices Forecast Exchange Rates? pp 1-45.

Fowowe, B (2014). Modelling the oil price - exchange rate nexus for South Africa, International Economics, pp 2-22

Ghosh, S (2010). Examining crude oil price - Exchange rate nexus for India during the period of extreme oil price volatility, Applied Energy 88 (2011) pp 1886 - 1889.

Goel, S., \& Sharma, R. (2015). Dynamics of exchange rate and crude oil price- evidence from India, The International Journal of Business \& Management, 3(1), pp 95-99.

Hamilton, J., 1989. A new approach to the economic analysis of nonstationary time series and the business cycle. Econometrica 57, pp357-384.

Hasanov, F, Mikayilov, J, Bulut, C, Suleymanov, E, and Aliyev, F (2017). The Role of Oil Prices in Exchange Rate Movements: The CIS Oil Exporters, Economies 2017, 5, 13; pp $1-18$.

Hashimova, K (2017). The Effect of Oil Price Fluctuations on the Exchange Rate of the National Currency of Azerbaijan: Assessment of the years 2014-2017, Center for Economic and Social Development (CESD).

Hotelling, H (1931). The Economics of Exhaustible Resources, Journal of Political Economy, Vol. 39, No. 2, pp 137-175.

Ji, Q, Liu, B, and Fan, Y (2018). Risk dependence of CoVaR and structural change between oil prices and exchange rates: A time-varying copula model. Eneeco (2018), doi:10.1016/j.eneco.2018.07.012.

Jiranyakul, K (2015). Oil Price Volatility and Real Effective Exchange Rate: The Case of Thailand, International Journal of Energy Economics and Policy, 2015, 5(2), pp 574-579.

Kaushik, N, Nag, R, and Upadhyaya, K, P (2014). Oil Price and Real Exchange Rate: The Case of India, International Business \& Economics Research Journal, Volume 13, Number 4, pp $809-814$. 
Kin, S, and Courage, M (2014). The Impact of Oil Prices on the Exchange Rate in South Africa, $J$ Economics, 5(2), pp 193-199.

Kouri, P. 1982. Balance of payments and the foreign exchange market: A dynamic partial equilibrium model. In The international transmission of economic disturbances, ed. J. Bhandari and B. Putnam. Cambridge: MIT Press.

Krugman, P. (1983), Oil shocks and exchange rate dynamics In Exchange Rates and International Macroeconomics, University of Chicago Press.

Kuan, C.M (2002). The Markov Switching Model, Institute of Economics, Academia Sinica, April 19,2002

Lizardo, R, and Mollick, A (2009). Oil price fluctuations and U.S. dollar exchange rates, Energy Economics 32 (2010) pp 399-408.

M, N, and Aimer, N (2016). The Impact Of Oil Price Fluctuations On The Exchange Rate In Libya, Imperial Journal of Interdisciplinary Research (IJIR), Vol-2, Issue-12, 2016, ISSN: 24541362, http://www.onlinejournal.in. pp $599-609$.

Muhammad, Z, Suleiman, H, and Kouhy, R (2011). Exploring oil price - exchange rate nexus For Nigeria, FIW Working Paper $\mathrm{N}^{\circ} 71$ September 2011.

Narayan, P, Narayan, S, and Prasad, A (2008). Understanding the oil price-exchange rate nexus for the Fiji islands, Energy Economics 30 (2008) pp 2686-2696.

Nouira, R, Amor, H, T, and Rault, C (2018). Oil Price Fluctuations and Exchange Rate Dynamics in the MENA Region: Evidence from Non-Causality-in-Variance and Asymmetric NonCausality Tests, CESifo Working Paper No. 7201, Category 12: Empirical and Theoretical Methods. pp $1-23$.

Nusair, S. A., and Kisswani, K. M. (2014). Asian real exchange rates and oil prices: A cointegration analysis under structural breaks, Bulletin of Economic Research, 67(1), pp 125 .

Ogundipe, M, O, Ojeaga, P, Ogundipe, A, A (2014). Oil Price and Exchange Rate Volatility in Nigeria, IOSR Journal of Economics and Finance (IOSR-JEF). Volume 5, Issue 4, 1p.

Osuji, E (2015). International Oil Prices and Exchange Rate in Nigeria: A Causality Analysis, International Journal of Academic Research in Economics and Management Sciences 2015, Vol. 4, No. 3, pp $11-22$.

Rickne, J (2009). Oil Prices and Real Exchange Rate Movements in Oil-Exporting Countries: The Role of Institutions, Research Institute of Industrial Economics, IFN Working Paper No. 810, 2009. pp 1-31. 
Salisu, A, and Mobolaji, H (2013). Modeling returns and volatility transmission between oil price and US-Nigeria exchange rate, Energy Economics 39 (2013) pp 169-176.

Selmia, F, Bouoiyourb, J, and Ayachic, F (2012). Another look at the interaction between oil price uncertainty and exchange rate volatility: The case of small open economies, Procedia Economics and Finance 1 (2012) pp $346-355$.

Shafi, K, Hua, L, Idrees, Z, Satti, A, J, Nazeer, A (2015). Exchange Rate Volatility and Oil Prices Shocks, International Journal of Academic Research in Business and Social Sciences, Vol. 5, No. 1, pp $249-256$.

Tiwari, A, and K, Dar, A, B, Bhanja, N (2013). Oil price and exchange rates: A wavelet based analysis for India, Economic Modelling 31 (2013) pp 414-422.

Turnovsky, S.J and Bhandari, J.S (1982). The Degree of Capital Mobility and Stability of an Open Economy under Rational Expectaions, Journal of Money, Credit and Banking, Vol. 14, No. 3 pp 303-326.

Volkov, N, and Yuhnb, K (2016). Oil price shocks and exchange rate movements, Global Finance Journal, pp 1-13.

Wu, M, and Yu, Y (2017). The Impact of Russia's Oil-Dominated Energy Economic Changes on the Exchange Rate of Russian Ruble - Chinese Renminbi, European Scientific Journal, August 2017 edition Vol.13, No.22, pp 173 - 191.

Yin, L, and Ma, X (2018). Causality between oil shocks and exchange rate: A Bayesian, graphbased VAR approach, Physica A (2018), https://doi.org/10.1016/j.physa.2018.05.064. 


\section{APPENDIX}

\section{Diagnostic Check}

Akaike's information criterion and Bayesian information criterion

\begin{tabular}{|c|c|c|c|c|c|c|}
\hline Model & Obs & 11 (null) & 11 (model) & $d f$ & $\mathrm{AIC}$ & $\mathrm{BIC}$ \\
\hline . & 152 & . & -626.4028 & 5 & 1262.806 & 1277.925 \\
\hline
\end{tabular}

Note: $\mathrm{N}=\mathrm{Obs}$ used in calculating BIC; see [R] BIC note.

Akaike's information criterion and Bayesian information criterion

\begin{tabular}{|c|c|c|c|c|c|c|}
\hline Model & Obs & 11 (null) & 11 (model) & $d f$ & $\mathrm{AIC}$ & $\mathrm{BIC}$ \\
\hline . & 152 & . & -597.0656 & 11 & 1216.131 & 1249.394 \\
\hline
\end{tabular}

Note: N=Obs used in calculating BIC; see [R] BIC note. 


\section{Figures}

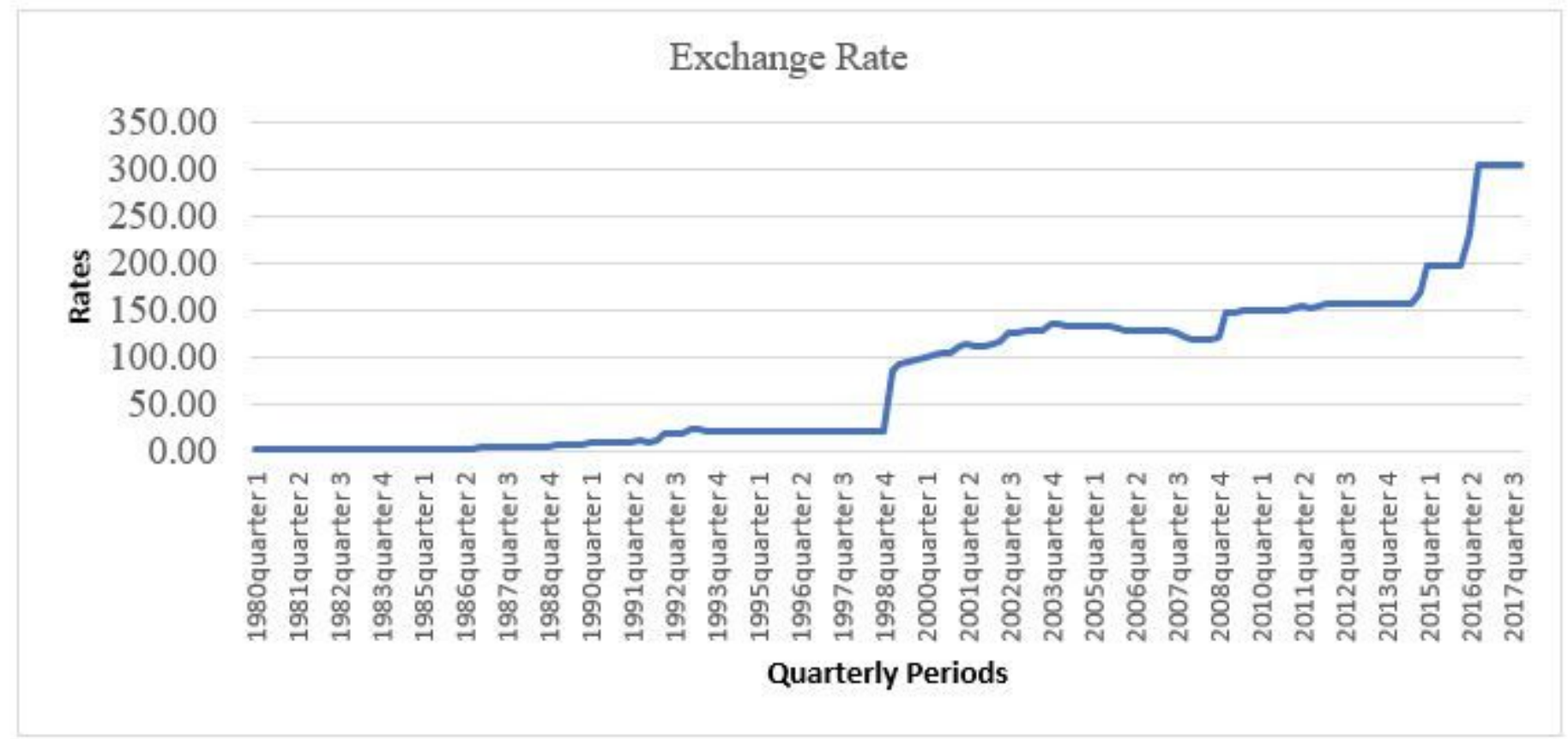

\section{Figure 1}

Exchange Rate (US\$:N1) Movement in Nigeria Source: CBN Statistical Bulletin (2018); World Development Indicators (WDI, 2018).

\section{Oil Price}

\section{0}

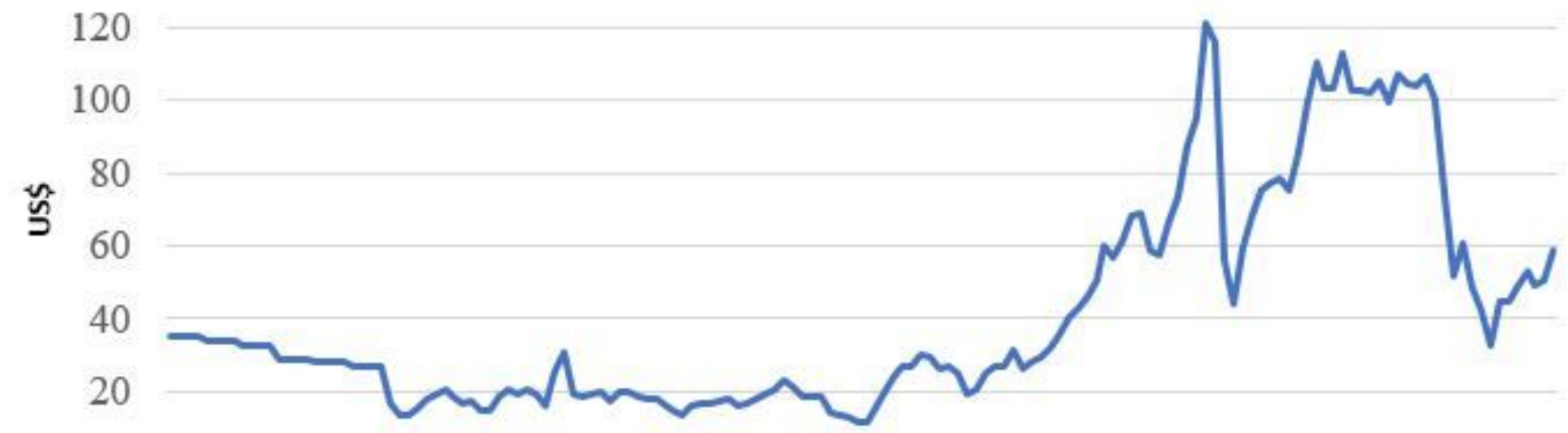

0

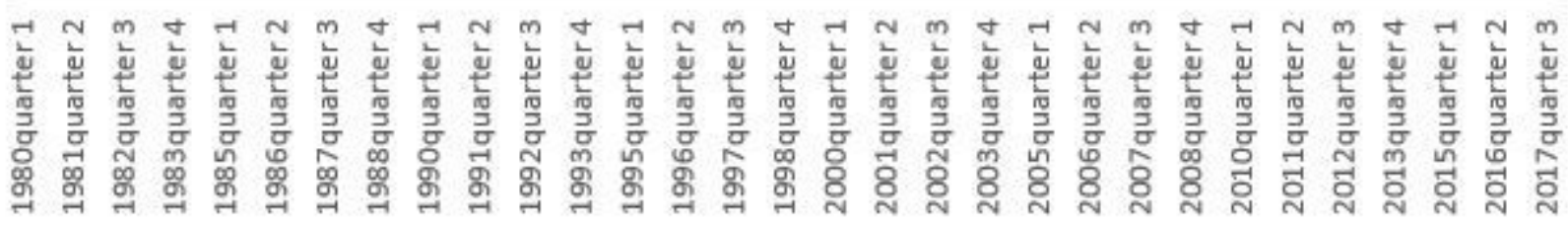


Figure 2

International Oil Price Source: CBN Statistical Bulletin (2018); World Development Indicators (WDI, 2018).

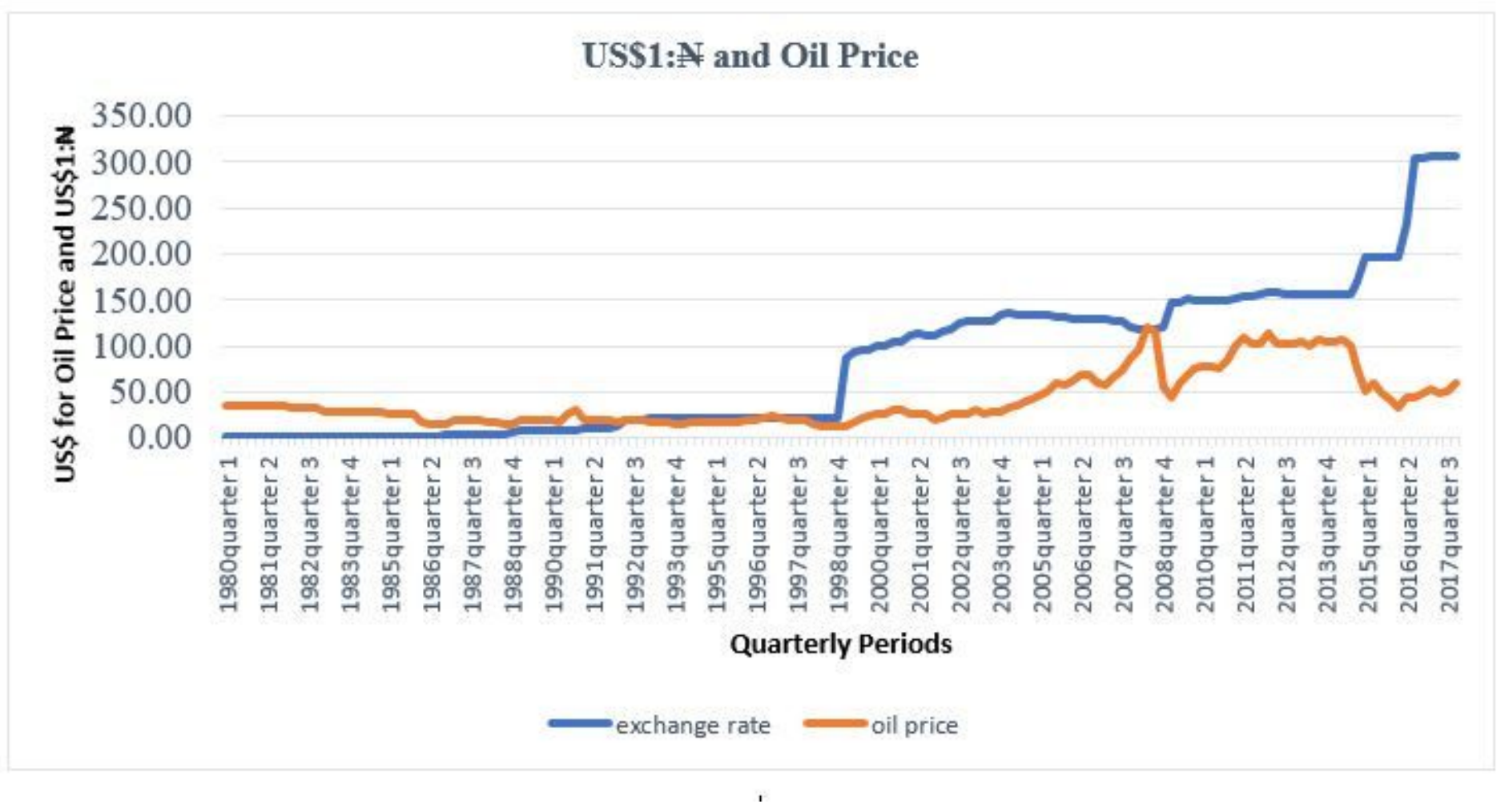

\section{Figure 3}

Exchange Rate Movement in Nigeria and International Price of Oil Source: CBN Statistical Bulletin (2018); World Development Indicators (WDI, 2018). 